\title{
In vitro diagnosis of sepsis: a review
}

This article was published in the following Dove Press journal:

Pathology and Laboratory Medicine International

9 March 2016

Number of times this article has been viewed

\section{Marcello Guido'}

Maria Rosaria Tumolo²

Antonella De Donno'

Tiziano Verri ${ }^{3}$

Francesca Serio'

Francesco Bagordo'

Antonella Zizza ${ }^{2}$

'Laboratory of Hygiene, Department of Biological and Environmental

Sciences and Technologies,

Faculty of Sciences, University of Salento, Lecce, Italy; ${ }^{2}$ National Research Council, Institute of Clinical Physiology, ${ }^{3}$ Laboratory of Physiology, Department of Biological and Environmental Sciences and Technologies, Faculty of Sciences, University of Salento, Lecce, Italy
Correspondence: Marcello Guido Laboratory of Hygiene, Department of Biological and Environmental Sciences and Technologies, Faculty of Sciences, University of Salento, Via Prov LecceMonteroni, 73 I00 Lecce, Italy $\mathrm{Tel} / \mathrm{Fax}+390832298686$

Email marcello.guido@unisalento.it
Abstract: Sepsis, severe sepsis and septic shock, systemic inflammatory response, and other related manifestations represent a relevant medical problem with high morbidity and mortality, despite the improvements in diagnosis, treatment, and preventive measures over the last few decades. The limited knowledge of the pathophysiology in association with the lack of in vitro diagnostic methods for the certain and quick determination of the causative microbiological agents and their antibiotic resistance means the condition is still critical and of high impact in health care. The current gold standard method to detect the sepsis-causing pathogens, which is based on blood culture, is still insufficiently sensitive and slow. The new culture-independent molecular biology-based techniques can lead to the identification of a broad range of microorganisms and resistance markers within a few hours and with high sensitivity and specificity; nevertheless, limitations of, for example, the polymerase chain reaction-based methods still hamper their application in the clinical routine. This review summarizes the in vitro diagnostic methods and their approach in the clinical diagnosis of the bloodstream infections, and explores their advantages and disadvantages at the current state of the art. A quick analysis of the future prospective in multiplex technologies for microbiological diagnosis of sepsis is also provided. Keywords: PCR, PCR/ESI-MS, microarray, MALDI-TOF, next-generation sequencing, FISH

\section{Introduction}

In 1992, sepsis was defined as a systemic inflammatory response syndrome (SIRS) to infection that results from an activation of the innate immune response, regardless of the cause. ${ }^{1}$ Sepsis can be associated with acute organ dysfunction, hypoperfusion, or hypotension (severe sepsis) or with arterial hypotension despite adequate fluid resuscitation after attempts of hemodynamic homeostasis maintenance are performed (septic shock). ${ }^{2}$ SIRS is considered to be present when there is more than one of the following clinical signs: a) body temperature $>38^{\circ} \mathrm{C}$ or $<36^{\circ} \mathrm{C}$; b) heart rate $>90$ beats per minute; c) hyperventilation evidenced by respiratory rate $>20 / \mathrm{min}$ or $\mathrm{PaCO}_{2}<32 \mathrm{mmHg}$; and d) white blood cell count $>12,000$ cells $/ \mu \mathrm{L}$ or $<4,000 / \mathrm{cells} / \mu \mathrm{L} .{ }^{3}$ In 2003 , the International Sepsis Definitions Conference (ACCP/SCCM) clarified that signs of a systemic inflammatory response occur in both inflammatory and non-inflammatory diseases, albeit difficult to analyze, and provided a list to discern sepsis from other conditions. Therefore, the terms sepsis and severe sepsis describe equally infections complicated by organ dysfunctions. ${ }^{4}$

Blood culture (BC) remains the "gold standard" method for pathogens identification in bloodstream infections (BSIs). ${ }^{5}$ A significant drawback of this method is that the submit your manuscript $\mid$ www.dovepress.com

Dovepress

http://dx.doi.org/10.2147/PLMI.S49800
Pathology and Laboratory Medicine International 2016:8 I-I4

(c) (i) (9) 2016 Guido et al. This work is published and licensed by Dove Medical Press Limited. The full terms of this license are available at https://www.dovepress.com/terms. (c) $\mathrm{BY}$ NG php and incorporate the Creative Commons Attribution - Non Commercial (unported, v3.0) License (http://creativecommons.org/licenses/lby-nch/3.0/). By accessing the work you hereby accept the Terms. Non-commercial uses of the work are permitted without any further permission from Dove Medical Press Limited, provided the work is properly attributed. For you hereby accept the Terms. Non-commercial uses of the work are permitted without any further permission from Dove Medical Priss
percial use of this work, please see paragraphs 4.2 and 5 of our Terms (https://www.dovepress.com/terms.php). 
time to positive organism identification may be 12 to $>72$ hours. Nevertheless, earlier detection of the etiological agent may have the potential to greatly benefit patient care. ${ }^{6}$ In the respect of patient's vulnerability, the guidelines for the treatment and management of sepsis recommend the prompt intravenous administration of broad-spectrum antibiotics within 1 hour of diagnosis, ${ }^{7}$ considering that a delay in the administration of antibiotic is generally associated with increased mortality. ${ }^{2,6}$ Notably, the lack of rapidity and the limited sensitivity of $\mathrm{BC}$ have prompted the scientific community to a growing interest in the development of novel molecular assays for detection and identification of BSIs in a much shorter time frame. ${ }^{2}$

The advent of the most recent molecular techniques and technologies is opening a new era in pathogens identification, even if their performance is hampered by the following: insufficient sensitivity; high costs; the presence of, for example, polymerase chain reaction (PCR) inhibitors; and need of highly trained staff. ${ }^{8}$ The purpose of the present review is to give an overview on the microbiological tests for the in vitro diagnosis of sepsis.

\section{Epidemiology of sepsis}

Sepsis is a clinical syndrome that affects $\sim 2 \%$ of patients hospitalized ${ }^{9}$ with higher frequency in those admitted to the intensive care unit and the emergency room, ${ }^{10,11}$ and with hematological malignancies and following surgery. ${ }^{12}$ Age, sex, race, and host genetic factors can influence the incidence and the outcome of severe sepsis, which is higher in infants and elderly than in other age groups, in males than in females, and in blacks than in whites. ${ }^{10,13}$ Many polymorphisms in genes encoding cytokines and other mediators of innate immunity, coagulation, and fibrinolysis are involved in sepsis mechanism. ${ }^{14}$

The rate of hospitalizations for sepsis is much higher for those aged $\geq 65$ years ( 122.2 per 10,000 population) than for those aged $<65$ years ( 9.5 per 10,000 population $){ }^{15}$

Sepsis is one of the leading causes of death in the world with an estimated incidence rate of up to 19 million people worldwide every year. ${ }^{16}$ Mortality rates range from $25 \%$ to $30 \%$ in severe sepsis cases and between $40 \%$ and $70 \%$ in patients with septic shock. ${ }^{17}$

Recent data declare that incidence rate is increasing each year, due to factors such as aging population, greater use of invasive techniques and surgical procedures, chronic diseases, immunosuppressive drugs, chemotherapy, transplantation, and increasing number of multidrug-resistant microorganisms. ${ }^{13,18-20}$
The central line-associated BSIs in intensive care unit, for example, cause a high mortality rate. ${ }^{21}$ In the US, the median rate ranges from 1.8 to 5.2 per 1,000 catheter days, according to the Centers for Disease Control and Prevention. ${ }^{22}$

The most common causes of sepsis are pneumonia and intra-abdominal and urinary tract infections. ${ }^{23}$

Gram-positive organisms are mainly responsible for sepsis, ${ }^{24}$ although recently, Gram-negative organisms are isolated in $62 \%$ of patients with severe sepsis, while fungi account for $19 \%$ of cases. ${ }^{25}$

Streptococcus pneumoniae is one of the most common microorganisms associated to sepsis, ${ }^{26}$ more frequent among elderly $>64$ years, ${ }^{27}$ and Pseudomonas aeruginosa has the highest mortality $(77 \%)$ of all. ${ }^{28}$

\section{Pathophysiology}

Sepsis, as an immune system-mediated syndrome, is one of the major causes of death, but its pathogenesis is not clear, especially with regard to dysfunction of the immune system. ${ }^{29}$

Systemic inflammatory response is based on a system of cellular activations with release of pro- and anti-inflammatory mediators that contribute to the onset of increasing clinical severity: SIRS $>$ sepsis $>$ severe sepsis $>$ septic shock. ${ }^{30}$

Sepsis develops when the innate immune response becomes amplified and dysregulated, leading to an imbalance between pro- and anti-inflammatory responses with the excessive release of cytokines and other inflammatory regulators. ${ }^{31}$

The early phase of sepsis is characterized by an excessive hyper-inflammatory reaction of the immune system, and subsequently, in the late phase, the release of antiinflammatory effectors (interleukin [IL]-4, IL-10, IL-13, cortisol, etc) and changes in T cells from Th1 to Th2 can induce a compensatory anti-inflammatory syndrome. ${ }^{32,33}$ In this state, with a compromised immune system, the body becomes more susceptible to secondary infections and viral reactivation. ${ }^{17}$

The organ dysfunction in severe sepsis depends directly on cytotoxic effects of inflammatory mediators, bacterial toxins, and tissue hypoxia. Commonly, patients develop the dysfunction of a single organ, which quickly turns into multiple organ failure. ${ }^{34}$

Reactive oxygen species and nitric oxide play a role in the pathophysiology of sepsis, as well. ${ }^{35}$ Furthermore, mitochondrial dysfunction has been implicated as a possible causative mechanism for the reduced activity of immune cells in sepsis. ${ }^{36}$ 


\section{Biological markers of sepsis}

The detection of sepsis-specific biomarkers for host response and pathogen identification can lead to both drug development and improved clinical management of sepsis. ${ }^{37}$

Because of the complex pathophysiology of sepsis that involves cell types, tissues, and organ systems, a recent systematic research identified nearly 180-200 distinct molecules as potential biological markers of sepsis. However, none of them has a specificity or sensitivity such that they can be used in clinical practice. ${ }^{38,39}$

Doherty et al defined a biomarker as "a characteristic that is objectively measured and evaluated as an indicator of normal biologic process or pathogenic process". ${ }^{40}$ Thus, in order to use a biomarker for clinical practice, it must have a high diagnostic accuracy, sensitivity, specificity, and both positive and negative predictive values. ${ }^{41}$ Moreover, a combination of several biomarkers may be useful to increase the diagnostic accuracy of the test in terms of sensitivity, specificity, and predictive values. ${ }^{42}$

The biomarkers of sepsis can be classified as markers of acute-phase protein (C-reactive protein [CRP], procalcitonin [PCT], lipopolysaccharide-binding protein), cytokine/ chemokine biomarkers (IL-6, IL-8), and markers of other pathophysiologic processes (coagulation factors and soluble cell surface receptors) ${ }^{43}$ Currently, complement factors (C3a, C5a, and the soluble form of the $\mathrm{C} 5 \mathrm{a}$ receptor, $\mathrm{cC} 5 \mathrm{aR}$ ) have been defined as early markers of sepsis and sepsis severity. ${ }^{44} \mathrm{CRP}$ and PCT are the most widely used for the detection of BSIs. ${ }^{38}$

\section{CRP}

CRP is a hepatic acute-phase protein ${ }^{41,45}$ with plasma concentration of $<10 \mathrm{mg} / \mathrm{L}$ that markedly increases during the infection (reaching levels $>200 \mathrm{mg} / \mathrm{L}$ ). ${ }^{46}$

This biomarker has been shown to have a higher sensitivity to temperature and white blood cell count, but it is less specific compared to $\mathrm{PCT}^{47}$

Although some authors suggest that higher plasma CRP concentration may help in distinguishing bacterial from viral and other infections, the clinical usefulness of such diagnostic approach remains unclear. ${ }^{48}$

\section{PCT}

PCT, a protein of 116 amino acids, is the peptide precursor of calcitonin, involved in calcium homeostasis. ${ }^{49}$

In bacterial infections, it has been demonstrated how plasma levels of PCT start to increase after 4 hours from the beginning of the systemic infection and reach the peak between 8 and 24 hours after. ${ }^{50}$
Plasma PCT levels $\leq 0.5 \mathrm{ng} / \mathrm{mL}$ suggest patients are unlikely to be suffering from severe sepsis or septic shock, while levels $>2 \mathrm{ng} / \mathrm{mL}$ identify patients with high risk. $^{49,51}$

Similar to CRP, it is uncertain if PCT can be used to distinguish between infections caused by Gram-positive and Gram-negative bacteria. ${ }^{52}$

\section{Therapeutic interventions}

Sepsis therapy is based on the use of targeted antibiotics that are necessary but not sufficient for the treatment. Guidelines recommend to immediately start a common broad-spectrum therapy (within 1 hour of sepsis diagnosis) in order to cover all likely pathogens. ${ }^{7}$ It remains controversial if combination antimicrobial therapy produces a better outcome than adequate single-agent antibiotic therapy in patients with sepsis. ${ }^{53-55}$ One major retrospective analysis of sepsis showed an increased mortality of $7.6 \%$ for each hour of delay in the administration of appropriate antibiotic. ${ }^{6}$

Despite extensive research in the last few decades to define sepsis and to improve the outcome of patients, it remains a challenge to identify the better therapeutic approach for clinical management and for survival of subjects.

The use of corticosteroids has been widely studied because with their anti-inflammatory properties, they inhibit the production of proinflammatory cytokines ${ }^{56}$ Many studies have not demonstrated beneficial effects in the treatment of septic patients with corticosteroids, while the administration at low doses for a long period can provide benefits in a subset of patients. ${ }^{57,58}$

Early goal-directed resuscitation therapy, a combination of crystalloid infusions, vasopressors or vasodilators, transfusion of packed red blood cells, and dobutamine, is recommended in international guidelines to patients presenting to the emergency department with early septic shock. ${ }^{59}$ But currently, its use remains controversial because resuscitation to static measurements of central venous pressure and central venous oxygen saturation did not increase survival of most patients. ${ }^{60}$

One of the effects of SIRS is the reduction of APC, a vitamin $\mathrm{K}$-dependent plasma protein, which has an anti-inflammatory effect; almost all sepsis patients have reduced concentration of APC, and lower levels are associated with worse outcomes. Because of bleeding risk associated with APC treatment, its therapeutic use is indicated only in patients with severe sepsis and organ failure. Administration of Drotrecogin alfa (Activated), a recombinant version of APC, has improved the survival 
of patients with severe sepsis and septic shock, who have high risk of mortality. ${ }^{61}$

Increased understanding of sepsis has demonstrated that it is not exclusively an inflammatory syndrome. A delicate balance exists between inflammatory and coagulation systems; in this regard, heparin for its anticoagulant and anti-inflammatory properties might be an ideal, and low-cost, treatment for sepsis. ${ }^{62}$ However, animal studies and clinical trials on heparin effectiveness are still limited.

Tissue factor pathway inhibitor has the same properties as heparin, but no study was able to demonstrate the potential benefit; nevertheless, further research is needed to evaluate its role in sepsis treatment. ${ }^{63}$

\section{Molecular techniques for assay of sepsis in positive $B C s$}

$\mathrm{BC}$ is the most sensitive method to detect the presence of bacteria or fungi in the blood so that the clinicians can be provided with information relevant for targeted therapy. ${ }^{64}$

$\mathrm{BC}$ test consists of laboratory investigations where the blood is inoculated into a proper culture medium and incubated. Media, used in BC bottles, support the growth of the most medically important bacteria and fungi. ${ }^{65,66}$

This test is capable of detecting as low as 1 colony forming unit (CFU) of bacteria or fungi per $10 \mathrm{~mL}$ blood. ${ }^{67}$

However, BC value for diagnosing bacteremia and/or sepsis is limited; in fact, up to $50 \%$ of all BCs collected are false-positive. ${ }^{68}$

Enriched growth media, adsorbing agents to neutralize growth inhibitors, software for more rapid detection of microorganisms, and growth and advances in automated agitation systems represent recent laboratory improvements for detection of pathogens. ${ }^{69,70}$

BC sensitivity for slow-growing and fastidious organisms can be poor, especially for bacteria that are responsible for community-acquired pneumonia, such as Mycoplasma pneumoniae, Legionella pneumophila, and Chlamydia pneumoniae, and for uncultivable pathogens, such as Francisella tularensis, Bartonella spp., Rickettsia spp., and Nocardia spp. ${ }^{67,71}$

A further complication in interpreting a $\mathrm{BC}$ test result is the presence of contaminations; in fact, many efforts have been made to reduce contaminated $\mathrm{BC}$ through, for example, the use of sterile gloves or prepackaged BC kits. ${ }^{72}$

Moreover, this test, including antimicrobial susceptibility, requires $>72$ hours for bacteria, and $>60$ hours for fungi, ${ }^{69}$ and BCs are always collected before initiating antibiotic therapy in order to increase the sensitivity. ${ }^{73}$
In spite of these limitations, a positive $\mathrm{BC}$ remains an important diagnostic clue or a confirmation for the physicians. The optimal assay result depends on volume of sample, moment of sampling, and accuracy with which this is carried out. ${ }^{71}$

We review different commercially available molecular techniques for the diagnosis of sepsis using positive $\mathrm{BC}$ as follows.

\section{Prove-it ${ }^{\mathrm{TM}}$ Sepsis}

The Prove-it ${ }^{\mathrm{TM}}$ assay (Mobidiag, Espoo, Finland) is one of the first commercially available microarray-based assays, which identifies sepsis-causing bacteria and fungi from positive BC in only 3 hours. ${ }^{74}$

The new improved version of Prove-it ${ }^{\mathrm{TM}}$ (Prove-it ${ }^{\mathrm{TM}}$ StripArray version 2.0) provides more comprehensive answers with less effort. In particular, it detects $\sim 80$ species of Gram-negative and Gram-positive bacteria, 13 species of fungi, as well as identifying $m e c A$, an antibiotic resistance marker used to identify methicillin-resistant Staphylococcus aureus. ${ }^{75}$

The Prove-it ${ }^{\mathrm{TM}}$ StripArray is based on broad-range PCR targeting conserved regions of gyr $B$, ParE, and mec $A$ genes followed by specific microarray that is capable of simultaneously processing from 1 to 96 samples at a time. It consists of eight successive reaction vials with a microchip at the bottom. The assay is easy to process, reducing the risk of human error and providing high throughput and reliability for the routine laboratory diagnosis. ${ }^{74,76,77}$

The main strength of the test is that it offers essential information for the treatment of septic patients 18 hours faster than traditional methods. Several papers have been presented indicating a high sensitivity and specificity (95\% and $99 \%$, respectively), although a lower diagnostic sensitivity (62\%) has also been observed, nevertheless in a previous study a significantly lower diagnostic sensitivity (62\%) was observed. ${ }^{78-80}$

A limitation of this approach is that it does not detect several clinically relevant pathogens, including Streptococcus viridans, Candida spp., and coagulase-negative staphylococci. ${ }^{74}$ Currently, the clinical usefulness of the test is limited because of its use only for BC.

\section{Verigene $^{\circledR}$}

The Verigene ${ }^{\circledR}$ Gram-Positive (BC-GP) and Gram-Negative Blood Culture (BC-GN) Assays (Nanosphere, Chicago, IL, USA) are random-access, automated tests that perform nucleic acid extraction directly from positive $\mathrm{BC}$ media, by hybridization to specific oligonucleotide-labeled gold 
nanospheres on a microarray. The system consists of a sample processor and a microarray reader. The result can be obtained in $\sim 2.5$ hours with $<5$ minutes of hands-on time. ${ }^{81,82}$

The BC-GP identifies 13 species/genus, including Staphylococcus spp., Streptococcus spp., Listeria spp., and Enterococcus spp., and three resistance markers (mecA, vanA, and vanB), whereas the BC-GN detects nine bacteria and six antimicrobial resistance genes (CTX-M for the detection of extended-spectrum beta-lactamases and IMP, KPC, NDM, OXA, and VIM for the detection of carbapenemase). ${ }^{82-84}$

One of the advantages of the assay is that it identifies more rapidly and accurately organisms and their antibiotic resistance genes, compared to traditional methods. For example, a major strength of BC-GP is the ability to differentiate several species of Staphylococcus, as well as the mecA gene. ${ }^{82,85}$ Verigene $^{\circledR}$ is limited to identifying certain species of fungi and Gramnegative bacteria. ${ }^{83}$ Another weakness is the lack of published cost-effectiveness analyses. ${ }^{85}$

The $\mathrm{BC}-\mathrm{GN}$ and $\mathrm{BC}-\mathrm{GP}$ are reliable, accurate, and rapid assays, which can be integrated into the routine workflow of a microbiology laboratory, even if their clinical benefits should be further evaluated.

These molecular diagnostic technologies enable the clinicians to provide optimized antibiotic therapy more quickly, potentially leading to improved patient outcomes and lower health care costs.

\section{FilmArray ${ }^{\circledR}$}

The FilmArray ${ }^{\circledR}$ (Biofire Diagnostics, Salt Lake City, UT, USA) is a multiplex PCR tool that tests for 24 sepsis-causing organisms and four antibiotic resistance genes such as mecA, vanA/B, and Klebsiella pneumoniae carbapenemase (blaKPC). ${ }^{86,87}$

The assay is based on the extraction and purification of nucleic acids from positive $\mathrm{BC}$ and amplification of the target genes by a reverse transcriptase first-stage PCR ${ }^{88}$

This simple system requires just a short hands-on time, with a total run time of $\sim 1$ hour, and only one sample can be analyzed at a time. ${ }^{86,88}$

The FilmArray ${ }^{\circledR}$ has a high performance in the identification of both Gram-negative and Gram-positive pathogens; in fact, it presents a sensitivity range from $88 \%$ to $100 \%$, and a specificity $>98 \%$ for all organisms. ${ }^{86}$

In a study reported by Altun et al, the test covered all microorganisms in $91.6 \%$ of positive BC bottles, and it had the potential to identify multiple pathogens simultaneously from positive $\mathrm{BC}$ with polymicrobial growth. ${ }^{87}$
This approach performs the extraction, amplification, and detection in a closed diagnostic system, minimizing contamination. It is a low-complexity system for the operator, requiring only injection of the BC sample into the pouch and starting the instrument; hence, the laboratory procedures can be performed by personnel with no training in molecular techniques. Another strength is the large number of targets, all evaluated in a single test, covering the majority of organisms determined in both adult and pediatric $\mathrm{BC}{ }^{88}$

Although FilmArray ${ }^{\circledR}$ and Verigene ${ }^{\circledR}$ are reliable and faster, neither of the systems can replace BC.

\section{MALDI-TOF MS}

Matrix-assisted laser desorption/ionization (MALDI) timeof-flight mass spectrometry (TOF MS) (Bruker Daltonics, Billerica, MA, USA; or BioMèrieux, Marcy l'Etoile, France) provides a method for rapid identification of bacteria and fungi (in $>90 \%$ of $\mathrm{BC}$ ) by determining their proteomic profiles. ${ }^{2,89}$

This platform functions by ionizing biomolecules (eg, nucleic acids, proteins, saccharides) separated through an electric field according to their mass-to-charge $(\mathrm{m} / \mathrm{z})$ ratio. ${ }^{90}$

Some of the benefits of MALDI-TOF MS, compared to traditional methods, are the rapid time to results (turnaround time of 1-2 hours), the simple protocol for sample preparation (reduced labor load), the low cost, and the ability to directly identify a large range of microorganisms. ${ }^{91,92}$ It presents a specificity of $\sim 96 \%$ and a sensitivity that varies between $76 \%$ and $98 \%$ depending on the pathogen..$^{93}$

One of MALDI-TOF MS drawbacks is that it exhibits reduced sensitivity for Gram-positive bacteria and polymicrobial infections with respect to conventional approaches; for example, it is not able to identify different species of the S. viridans group. ${ }^{94}$ Furthermore, this proteomic technology cannot be applied directly to whole blood; a subculture is necessary. ${ }^{2}$

MALDI-TOF MS, as well as PCR amplification combined to electrospray ionization mass spectrometry (PCR/ESI-MS) (explained in the following paragraph), results in a promising tool in clinical and epidemiological management.

\section{PCR/ESI-MS analysis}

A new approach to the diagnosis of sepsis developed by Abbott permits the identification of bacterial species directly from both positive $\mathrm{BC}$ and whole blood. The analysis by $\mathrm{BC}$ is described later. The test combines a broad-range PCR amplification (it uses primers that recognize bacterial/fungal 
conserved genetic sequences encoding ribosomal DNA) with electrospray ionization mass spectrometry (Abbott Molecular, Ibis Biosciences, Carlsbad, CA, USA) for identification of pathogens and associated antibiotic resistance. ${ }^{95}$

Conversely to MALDI-TOF MS, it uses genetic information to identify microorganisms. ${ }^{96}$ This permits the ability to detect silent mutations, and to access antibiotic resistance genes, thus providing a mechanism for rapid antibiotic susceptibility testing.

The method uses primers that are designed to target genomic regions sufficiently conserved such that amplification occurs comprehensively within a biothreat cluster. Then, the amplification products are analyzed by mass spectrometry. The turnaround is $\sim 4-6$ hours after positive BC, ${ }^{97}$ and this assay permits analysis of six samples a time..$^{98}$

This platform shows high analytical accuracy in comparison to routine subculture of BC bottles. ${ }^{96,99}$

A major advantage of this method is the ability to characterize an organism without previous knowledge and to analyze mixtures of microbes directly from raw BC broth without the need for separation of colonies by subculturing.

The platform was initially established on a first model instrument (Abbott Molecular T5000 PCR/ESI-MS). However, the T5000 was hampered by a number of significant mechanical malfunctions; thus, to overcome these limitations, a newer model of this instrument, called the PLEX-ID, has been designed to be more robust and is provided with a software interface more suitable for use in the clinical laboratory. ${ }^{96,99}$ The PLEX-ID BAC Spectrum BC assay that runs on the PLEX-ID permits identification of $>600$ bacteria and Candida spp., and it also detects resistance genes for four clinically relevant antibiotic resistance genes mec $A, v a n A / B$, and blaKPC. ${ }^{97}$ Further details on the PLEX-ID system for microorganism detection using whole blood are given later in this review.

\section{Hybridization: PNA-FISH ${ }^{\circledR}$ and REBA}

Fluorescent in situ hybridization (FISH) tests have been used in rapid diagnosis of BSIs for more than a decade. ${ }^{100}$ The technique is based on fluorescently labeled oligonucleotide probes specific for ribosomal RNA, which have been used to detect $>95 \%$ of bacteria and fungi in BC. ${ }^{101,102}$ The most commonly used target in prokaryotes is $16 \mathrm{~S}$ rRNA. ${ }^{103}$ The assay allows the identification of many pathogens in only 2.5-3 hours. ${ }^{101}$

The PNA-FISH (AdvanDx Inc., Woburn, MA, USA) is a new FISH test that uses peptide nucleic acid (PNA) probes, mimicking the DNA or the RNA structure, to detect microorganisms without a step of amplification, thus reducing contamination risk. ${ }^{104}$

Its turnaround is $\sim 3$ hours due to the drying phases and the incubation period; the test does not detect as many pathogens as the Prove-it ${ }^{\mathrm{TM}}$ assay (only ten microorganisms). ${ }^{2,105} \mathrm{It}$ presents an excellent sensitivity and specificity $>98 \%{ }^{106}$

A comparative study, conducted by Calderaro et al, between the PNA-FISH and the MALDI-TOF MS shows more advantages of the first with respect to the second method. In fact, even if the MALDI-TOF MS is an inexpensive method and a drawback of the PNA-FISH is the limited spectrum of recognized bacteria, the latter requires only basic laboratory equipment, and the results of this study suggest its usefulness in the cases of mixed infections. ${ }^{107}$

The main strength of the assay is the quick procedure that enables a targeted and shorter therapy, increases benefits for patients, and reduces health care costs. ${ }^{108}$

The reverse blot hybridization assay (REBA) is a molecular tool that uses multiple probes for the detection and the simultaneous identification of Gram-positive and Gram-negative pathogens, and mecA and van genes from $\mathrm{BC}$. Therefore, the REBA test may be able to detect nonviable bacteria or those at a low concentration that are not detectable by BC. Thus, the REBA test may have practical benefits in the clinical setting, particularly for patients on empirical antibiotic treatment before culture results are obtained. Another advantage is that antibiotic resistance can be determined within a few hours of BC sampling. ${ }^{109}$

\section{Molecular techniques for assay of sepsis in whole blood}

Techniques for diagnosis of BSI are constantly evolving and need further improvements to reduce the response time in order to have greater potential to positively impact patient care. Molecular assays applied directly on whole blood samples are the best choice to detect the pathogens, although they cannot replace the $\mathrm{BC}$ but are complementary to culturebased diagnosis. ${ }^{110}$

\section{LightCycler ${ }^{\circledR}$ SeptiFast assay}

The LightCycler ${ }^{\circledR}$ SeptiFast assay, a multi-pathogen probe-based real-time PCR (Roche Diagnostics, Basel, Switzerland), detects and identifies a wide range of bacteria and fungi causing BSIs directly from $1.5 \mathrm{~mL}$ whole blood, without pre-culture. ${ }^{111}$

The test is based on dual-labeled fluorescent energy transfer probes targeting the species-specific internal transcribed spacer regions of bacteria and fungi. ${ }^{77}$ 
The LightCycler ${ }^{\circledR}$ SeptiFast assay is capable of identifying 25 different sepsis-causing pathogens and the mecA gene associated with methicillin resistance in $S$. aureus in $<6$ hours. The detection of the pathogen by this molecular diagnostic tool permits the rapid diagnosis of bacteremia/ fungemia and an earlier administration of appropriate antibiotic therapy. ${ }^{112,113}$

The detection limit is $100 \mathrm{CFU} / \mathrm{mL}$ for Candida glabrata, Streptococcus spp., and coagulase-negative Staphylococcus, and ranges from 3 to 30 for the others, depending on the infective agent. ${ }^{114}$

Limitations include its high cost (150-200 € per test), trained personnel requirement, and lack of information on antibiotic sensitivity. ${ }^{2,115}$

The assay has shown variable levels of sensitivity and specificity; ${ }^{111,116}$ in particular, sensitivity was $80 \%$ and specificity $95 \%$ for bacteria, whereas $61 \%$ and $95 \%$ for fungi. ${ }^{79,114}$

Several studies on neutropenic, general medicine, and intensive care patients have shown reliable results in the diagnosis of BSIs through a combination of SeptiFast and $\mathrm{BC}$ assays, particularly when a fungal infection is suspected. ${ }^{117-119}$

Furthermore, other literature data suggest that SeptiFast might be a valuable complementary tool to manage patients with clinically suspected sepsis. ${ }^{120}$

This assay represents an important alternative to $\mathrm{BC}$, mostly for its short time to get the result and the high specificity, although further advancements in laboratory staffing and workflows are necessary to improve its suboptimal sensitivity.

\section{SepsiTest ${ }^{\circledR}$}

The SepsiTest ${ }^{\mathbb{}}$ (Molzym, Bremen, Germany) includes DNA extraction of samples and PCR or real-time PCR using primers targeting conserved regions of the $16 \mathrm{~S}$ and $18 \mathrm{~S}$ rRNA genes of bacteria and fungi. After PCR, gel electrophoresis and sequencing are performed. Results are considered positive if sequencing is successful. ${ }^{121}$

A broad spectrum of Gram-negative, Gram-positive, and fungal organisms $(>300)$ were identified by this assay. Compared to $\mathrm{BC}$, this approach displays a diagnostic sensitivity and a specificity of $87 \%$ and $86 \%$, respectively. ${ }^{122}$

One of the advantages of this procedure is that low blood volume is required. ${ }^{123}$ Conversely, the procedure is limited by its turnaround (requiring from 8 to 12 hours of work) due to several steps (DNA extraction, PCR amplification, sequencing, online sequence identification), and consequently, the risk of contaminations is increased. ${ }^{124,125}$
In a multicenter study that evaluates the SepsiTest ${ }^{\mathbb{B}}$ diagnostic accuracy, the assay was applied on 342 samples from 187 patients with SIRS, sepsis, or neutropenic fever; the results showed a higher rate of positivity compared to BCs. ${ }^{122}$

As soon as its cost and time to result decrease, the assay will be considered a reliable tool for clinicians in patient care and will represent a useful supplemental method in the diagnosis of sepsis.

\section{$\mathrm{VYOO}^{\circledR}$}

The VYOO $^{\circledR}$ (SIRS Lab, Jena, Germany) is a diagnostic multiplex PCR method for qualitative detection of specific bacteria and fungi from 1.0 to $5 \mathrm{~mL}$ blood sample. It consists of mechanical lysis of whole blood, automated total DNA extraction, and pathogen DNA enrichment by affinity chromatography. Then, the pathogen-enriched DNA is amplified and analyzed by a run on agarose gel. ${ }^{77,79}$

The test specifically identifies 39 sepsis-related pathogens (32 bacterial species and seven fungal species) and five resistance genes such as the mecA, vanA/B, B-lactamase blaSHC, and blaCTX-M genes. ${ }^{2,77,79}$

The main advantage of this PCR-based assay, compared to $\mathrm{BC}$, is the turnaround ( 8 hours vs $1-3$ days) ${ }^{70,79}$ while the limitation is the number of pathogens that may be identified at the species level and the low specificity of the electrophoresisbased identification. ${ }^{110}$

The $\mathrm{VYOO}^{\circledR}$ assay has been used in a study in which 24 patients with severe sepsis and 22 with SIRS were examined. In sepsis patients, the $\mathrm{VYOO}^{\circledR}$ gave more positive results than $\mathrm{BC}$, whereas in SIRS patients, $\mathrm{BC}$ was positive in five cases, but no pathogens were determined by the PCR. ${ }^{126}$

Using the $\mathrm{VYOO}^{\circledR}$ assay, clinicians can rapidly and reliably identify causative pathogens as well as important antibiotic resistance markers. A main limitation for its clinical validation is the technical training required to support the laboratory procedures.

\section{Magicplex ${ }^{\mathrm{TM}}$ sepsis real-time}

Magicplex ${ }^{\mathrm{TM}}$ assay (SeeGene, Seoul, Korea) is a multistep approach that associates conventional PCR and real-time PCR and screens for $>90$ pathogens ( 73 Gram-positive, 12 Gram-negative, and six fungi) as well as three drug resistance markers (mecA and $v a n A / B$ ) from whole blood samples. Also, 27 pathogens can be identified to the species level. ${ }^{124}$ The method uses the SelectNA ${ }^{\mathrm{TM}}$ blood pathogen kit to extract DNA, requiring $<1 \mathrm{~mL}$ of whole blood, while a dual priming oligonucleotide (two functional priming 
regions separated by a polylinker) is used for the amplification step. ${ }^{127}$

It provides results within 6 hours including several steps (pretreatment of specimens, extraction of DNA, screening amplification, and amplification to identify the pathogens) and different devices. ${ }^{124,127}$

In the first study that has evaluated the clinical performance of the assay, ${ }^{127}$ Carrara et al have shown a nearly equal sensitivity compared to BC (65\% vs $71 \%)$. The sensitivity value was comparable to the rate measured in another study (64\%), as well as the specificity value (92\% vs $96 \%) .{ }^{80}$ Conversely, Loonen et al while investigating the performance of the assay found a sensitivity and specificity of $37 \%$ and $77 \%$, respectively. ${ }^{124}$ Nevertheless, despite its low sensitivity, the test is an accurate tool to determine bacteria, mostly those belonging to Enterobacteriaceae. ${ }^{128}$

A negative point of the Magicplex ${ }^{\mathrm{TM}}$ is the contamination risk of PCR reagents by amplicons. ${ }^{127}$

Further advancements in the technology (eg, for processing a larger volume of blood to increase diagnostic sensitivity) are necessary to improve its clinical validation.

\section{PLEX-ID}

PLEX-ID (Abbott Molecular, Ibis Biosciences, Carlsbad, CA, USA) is a novel and universal method for diagnosis of a broad range of pathogens and four resistance markers ( $m e c A$, $v a n A / B$, and blaKPC) directly from the patient's blood. ${ }^{129}$
As previously described, this process includes automated DNA extraction, PCR setup, PCR amplification, amplicon purification, and PCR/ESI-MS. It consists of PCR, using nine primer pairs targeting 16S rDNA, 23S rDNA, and four housekeeping genes, and ESI-MS for amplicon analysis. ${ }^{95,97}$

In a newer version of PCR/ESI-MS, IRIDICA (Ibis Biosciences), the volume of blood used is enhanced ( $5 \mathrm{~mL}$ instead of $1.25 \mathrm{~mL}$ ) in order to increase sensitivity. Furthermore, improved sensitivity is also achieved by the use of specific primers. ${ }^{129}$

Another improvement is that one to six specimens can be analyzed at a time. ${ }^{97}$

Rapid turnaround time (5-6 hours) in both is provided by the use of ESI-MS rather than Sanger sequencing. ${ }^{130}$

This approach shows a sensitivity of $83 \%$ and a specificity of $94 \%$ compared to BC. ${ }^{131}$ A major strength of PLEX-ID is the possibility to evaluate both sterile and nonsterile blood samples. IRIDICA is able to detect an extra 80 microorganisms that did not grow in BC. ${ }^{110,129}$

Nowadays, the IRIDICA technology represents a reliable test in the diagnosis of BSIs directly from whole blood, but more studies on costs/benefits are needed to evaluate its use in the clinical diagnostics.

Tables 1 and 2 summarize the main characteristics of assays for identification of microbes directly from $\mathrm{BC}$ and whole blood.

Table I Commercially available molecular techniques for the diagnosis of sepsis using positive blood cultures

\begin{tabular}{|c|c|c|c|c|c|c|c|}
\hline Assay & Manufacturer & $\begin{array}{l}\text { Principles of the } \\
\text { assay }\end{array}$ & $\begin{array}{l}\text { Pathogens } \\
\text { detected }(\mathbf{N})\end{array}$ & $\begin{array}{l}\text { Execution } \\
\text { time (hours) }\end{array}$ & $\begin{array}{l}\text { Sensitivity } \\
(\%)\end{array}$ & $\begin{array}{l}\text { Specificity } \\
\text { (\%) }\end{array}$ & Ref \\
\hline $\begin{array}{l}\text { Prove-it }{ }^{\mathrm{TM}} \\
\text { Sepsis }\end{array}$ & $\begin{array}{l}\text { Mobidiag, Espoo, } \\
\text { Finland }\end{array}$ & $\begin{array}{l}\text { Multiplex PCR } \\
\text { combined with } \\
\text { microarray }\end{array}$ & $\begin{array}{l}83 \text { pathogens (I9 GP, } \\
5 \text { I GN, I3 fungi), } 3 \text { DRM }\end{array}$ & 3 & 94.7 & 98.8 & 74 \\
\hline $\begin{array}{l}\text { Verigene }^{\circledast} \\
\text { BC-GP }\end{array}$ & $\begin{array}{l}\text { Nanosphere, } \\
\text { Chicago, IL, USA }\end{array}$ & $\begin{array}{l}\text { Hybridization on } \\
\text { microarray }\end{array}$ & 9 species, 4 genera, 3 DRM & 2.5 & $50-100$ & $98.8-100$ & $81,83,84$ \\
\hline $\begin{array}{l}\text { Verigene }^{\circledR} \\
\text { BC-GN }\end{array}$ & $\begin{array}{l}\text { Nanosphere, } \\
\text { Chicago, IL, USA }\end{array}$ & $\begin{array}{l}\text { Hybridization on } \\
\text { microarray }\end{array}$ & 5 species, 4 genera, 6 DRM & 2 & $50-100$ & $99.4-100$ & $83,84,132$ \\
\hline FilmArray ${ }^{\circledR}$ & $\begin{array}{l}\text { Biofire Diagnostics, } \\
\text { Salt Lake City, UT, } \\
\text { USA }\end{array}$ & $\begin{array}{l}\text { Multiplex PCR } \\
\text { system }\end{array}$ & $\begin{array}{l}24 \text { pathogens (8 GP, II GN, } \\
5 \text { species of Candida), } 4 \text { DRM }\end{array}$ & I & $88-100$ & $>98$ & $79,86,87$ \\
\hline PNA-FISH & $\begin{array}{l}\text { AdvanDx Inc., } \\
\text { Woburn, MA, USA }\end{array}$ & $\begin{array}{l}\text { Fluorescence in } \\
\text { situ hybridization } \\
\text { with PNA probes }\end{array}$ & $\begin{array}{l}12 \text { pathogens, ( } 5 \text { GP, } 2 \text { GN, } \\
5 \text { species of Candida) }\end{array}$ & $2-3$ & 99 & 100 & $2,70,134,135$ \\
\hline $\begin{array}{l}\text { MALDI-TOF } \\
\text { MS }\end{array}$ & $\begin{array}{l}\text { Bruker Daltonics, } \\
\text { Billerica, MA, USA; or } \\
\text { BioMèrieux, l'Etoile, } \\
\text { France }\end{array}$ & Mass spectrometry & Hundreds of pathogens & $\mathrm{I}-2$ & $76-98$ & $>96$ & $91,93,133$ \\
\hline PLEX-ID BAC & $\begin{array}{l}\text { Abbott Molecular, } \\
\text { lbis Biosciences, } \\
\text { Carlsbad, CA, USA }\end{array}$ & $\begin{array}{l}\text { Multiplex real-time } \\
\text { PCR/ESI-MS }\end{array}$ & $\begin{array}{l}>600 \text { bacteria and Candida } \\
\text { species of } 4 \text { DRM }\end{array}$ & $4-6$ & 95 & 98.9 & $96,97,99$ \\
\hline
\end{tabular}

Abbreviations: PCR, polymerase chain reaction; GP, Gram-positive; GN, Gram-negative; DRM, drug-resistant marker; BC-GP, Gram-positive blood culture; BC-GN, Gram-negative blood culture; PNA-FISH, peptide nucleic acid-fluorescent in situ hybridization; MALDI-TOF MS, matrix-assisted laser desorption/ionization time-of-flight mass spectrometry; ESI-MS, electrospray ionization mass spectrometry; Ref, reference. 
Table 2 Commercially available molecular techniques for assay of sepsis in whole blood

\begin{tabular}{|c|c|c|c|c|c|c|c|}
\hline Assay & Manufacturer & $\begin{array}{l}\text { Principles of } \\
\text { the assay }\end{array}$ & $\begin{array}{l}\text { Pathogens detected } \\
\text { (N) }\end{array}$ & $\begin{array}{l}\text { Execution } \\
\text { time (hours) }\end{array}$ & $\begin{array}{l}\text { Sensitivity } \\
\text { (\%) }\end{array}$ & $\begin{array}{l}\text { Specificity } \\
\text { (\%) }\end{array}$ & Ref \\
\hline $\begin{array}{l}\text { LightCycler }{ }^{\circledR} \text { SeptiFast } \\
\text { Test MGRADE }\end{array}$ & $\begin{array}{l}\text { Roche } \\
\text { Diagnostics, Basel, } \\
\text { Switzerland }\end{array}$ & $\begin{array}{l}\text { Multiplex real- } \\
\text { time PCR }\end{array}$ & $\begin{array}{l}25 \text { pathogens } \\
\text { (I0 GN, } 9 \text { GP, } 6 \text { fungi), } \\
\text { mecA genes }\end{array}$ & 6 & $79.0-91.3$ & $88.1-96.0$ & $79,111,114,116$ \\
\hline SepsiTest ${ }^{\circledR}$ & $\begin{array}{l}\text { Molzym, Bremen, } \\
\text { Germany }\end{array}$ & $\begin{array}{l}\text { Broad-range PCR } \\
\text { with sequencing }\end{array}$ & $>345$ pathogens & $8-12$ & 87.0 & 85.8 & $2,77,110,122$ \\
\hline VYOO ${ }^{\circledR}$ & $\begin{array}{l}\text { SIRS Lab, Jena, } \\
\text { Germany }\end{array}$ & $\begin{array}{l}\text { Multiplex real- } \\
\text { time PCR with } \\
\text { electrophoresis }\end{array}$ & $\begin{array}{l}39 \text { pathogens (14 GP, } \\
18 \mathrm{GN}, 7 \text { fungi), } 5 \text { DRM }\end{array}$ & 8 & 60.0 & 75.0 & $2,77,79,110,136$ \\
\hline $\begin{array}{l}\text { MagicPlex }{ }^{\mathrm{TM}} \text { sepsis } \\
\text { real-time }\end{array}$ & $\begin{array}{l}\text { Seegene, Seoul, } \\
\text { Korea }\end{array}$ & $\begin{array}{l}\text { Multiplex real- } \\
\text { time PCR }\end{array}$ & $\begin{array}{l}\text { 9I pathogens ( } 73 \mathrm{GP} \text {, } \\
\text { I } 2 \mathrm{GN}, 6 \text { fungi), } 3 \mathrm{DRM}\end{array}$ & 6 & 65 & 92 & $79,127,135$ \\
\hline IRDICA & $\begin{array}{l}\text { Abbott Molecular, } \\
\text { lbis Biosciences, } \\
\text { Carlsbad, CA, USA }\end{array}$ & $\begin{array}{l}\text { Multiplex real- } \\
\text { time PCR/ESI-MS }\end{array}$ & $\begin{array}{l}\text { Up to } 800 \text { pathogens, } \\
4 \text { DRM }\end{array}$ & 6 & 83 & 94 & $95,96,|29| 3 \mid$, \\
\hline
\end{tabular}

Abbreviations: PCR, polymerase chain reaction; GN, Gram-negative; GP, Gram-positive; DRM, drug-resistant marker; ESI-MS, electrospray ionization mass spectrometry; Ref, reference.

\section{Sequencing}

MicroSEQ 500 Kit (Perkin-Elmer Applied Biosystems, Waltham, MA, USA) and pyrosequencing (Biotage, Uppsala, Sweden) represent sequencing technologies to identify microorganisms in positive $\mathrm{BC}$ and from whole blood in a fast turnaround and with lower costs compared to conventional Sanger method. ${ }^{70,137}$ The first involves amplification and sequencing of the first $527 \mathrm{bp}$ fragment of the 16S rRNA genes of bacterial strains, ${ }^{138}$ and the second has been used to classify and identify a variety of bacterial $16 \mathrm{~S}$ rDNA fragments. ${ }^{137}$

Currently, the next-generation sequencing (NGS) technology (eg, Illumina MiSeq) represents a new challenge to identify and genotype viable, dead, and viable but nonculturable pathogens, and antibiotic resistance markers, and it provides significant input to scientific discovery due to its cheap cost and fast turnaround. ${ }^{92,139,140}$

The biggest challenge in applying NGS to BSIs is the detection of very small amounts of pathogen nucleic acid in the vast excess of human genomic DNA. ${ }^{79}$

\section{Discussion and conclusion}

The high incidence and severity of systemic infections can be ascribed to several factors, among which are the immaturity of the immune defense mechanisms and the complex interactions between pathogens and host.

Sepsis, in fact, is a pathological condition triggered by microorganisms and induced by inflammatory mediators, which causes alteration of the immune, inflammatory, and coagulative equilibrium. Disease progression and clinical manifestation depend on a complex and delicate balance between pro- and anti-inflammatory factors. ${ }^{31}$

The clinical evolution of disease can greatly differ among subjects and sometimes be extremely fast and severe; therefore, an early and rapid identification of the causative agents and the sequential application of the targeted therapies are the necessary conditions for improving patient survival. Strategies have thus to be started on the primary care level in order to manage all patients outside of modern intensive care.

The incidence of sepsis continues to increase, and its diagnosis remains a major challenge for immunosuppressed subjects, given that over half of patients suspected of having sepsis are culture-negative. ${ }^{141}$

Incorrect diagnosis and inappropriate antibiotic administration seem to be the most common causes of sepsis-associated mortality. It has thus become an increasingly urgent need to search for new methods to improve sensitivity and speed of diagnosis.

$\mathrm{BC}$ is still considered the "gold standard" for treatment of sepsis, even if in many cases it remains a tool insufficiently sensitive and too slow. ${ }^{9}$

The response time of $\mathrm{BC}$ can be 2 days or longer; furthermore, in particular for certain disorders, it is too long to allow physicians to make a targeted antibiotic therapy. Despite recent progress to optimize the technique, the sensitivity for the detection of certain pathogens remains poor, and the contamination of BC continues to be a significant problem. Communityacquired pneumonia, invasive fungal infections, and endocarditis are caused by pathogens difficult to detect, that therefore are responsible for high mortality in untreated patients. The contamination rate is still estimated to be $\sim 3 \%$, despite operators with specialized expertise being involved in sampling and laboratory procedures, and that prepackaged $\mathrm{BC}$ kits and sterile material have been introduced to reduce the contamination.

Several studies have shown that many factors may reduce the sensitivity of BC. The most important are the blood volume and the time from sampling to incubation. The first is confirmed 
in studies on pediatric patients where the rate of isolation from $\mathrm{BC}$ increases with a low quantity of blood submitted, ${ }^{142}$ whereas the second considers that BC should be processed immediately to decrease the number of false-negative samples. ${ }^{143}$

Recently, new methods have been developed to reduce the time of diagnosis, and to improve the sensibility and the clinical benefits of detection of pathogens. The molecular detection techniques have allowed early identification of more pathogens and important resistance genes compared to conventional BC.

The short turnaround times of molecular assays may be of clinical importance in the management and the outcome of sepsis patients, since a delayed antibiotic treatment significantly increases mortality rates. In this respect, some research shows that culture-independent molecular assays, such as LightCycler ${ }^{\circledR}$ SeptiFast (Roche Diagnostics) and Magicplex ${ }^{\mathrm{TM}}$ assay (SeeGene), are very swift with a turnaround time between 3.5 and 6 hours. ${ }^{114,124}$

Moreover, the opportunity of reducing the time to set up an optimal and effective antimicrobial therapy has allowed a drastic reduction of health care costs associated with inappropriate treatments resulting in prolonged length of hospital stay.

BC permits detection of very low numbers of infecting agents, ${ }^{144}$ while the molecular assays directly from whole blood cover a broad range of pathogens causing sepsis. ${ }^{145,146}$ In this respect, literature data document that SepsiTest ${ }^{\circledR}$ (Molzym) and PLEX-ID (Abbott Molecular) identify the largest number of pathogens $\left(>300^{122}\right.$ and up to 800 microorganisms, respectively)..$^{95}$

A limit of PCR-based assays is the impossibility to provide information on antimicrobial susceptibility of the detected pathogen.

Another drawback of these tools is their high cost that includes need of equipment, reagents, and skilled personnel available for a long time.

MALDI-TOF MS and PCR/ESI-MS, due to their rapid pathogen detection, reduced labor load (specialized personnel is not required), and inexpensive methods, are widely used in the identification of microorganisms in BC and directly from whole blood; nevertheless, their performance is hampered by their limited ability to test for antimicrobial susceptibility of bacteria.

Hence, despite the advantages of molecular techniques in terms of sensitivity and promptness, the antibiotic resistance spectrum can only be achieved by BC. Thus, none of the molecular tests can replace $\mathrm{BC}$, but they are complementary and must be applied in combination in order to reach a correct and faster diagnosis.
Further advances in the near future are required in order to overcome the shortcomings of BC- and PCR-based assays. The new techniques should improve the limited analytical sensitivity for determination of pathogens difficult to detect and to distinguish between viable and dead bacteria.

A first step in this regard is the development of the Genalysis $^{\circledR}$ platform produced by DNA Electronics Ltd (London, UK), ${ }^{147}$ which can perform both PCR and sequencing on the same chip in the same analysis to arrive at a fast, accurate, and informative diagnosis.

NGS technologies allow a fast identification of pathogens (2-3 hours) and have the potential to reveal at the same time the pathogen specimens and antimicrobial susceptibility.

Future research and technological developments should be performed to find bioinformatic tools and sequencing platforms that speed up the procedure, and become simpler and less expensive in order to get to the "new gold standard" for BSI diagnosis.

\section{Disclosure}

The authors report no conflicts of interest in this work.

\section{References}

1. American College of Chest Physicians/Society of Critical Care Medicine Consensus Conference: definitions for sepsis and organ failure and guidelines for the use of innovative therapies in sepsis. Crit Care Med. 1992;20(6):864-874.

2. Mancini N, Carletti S, Ghidoli N, et al. The era of molecular and other non-culture-based methods in diagnosis of sepsis. Clin Microbiol Rev. 2010;23(1):235-251.

3. Bone RC. Toward an epidemiology and natural history of SIRS (Systemic Inflammatory response syndrome). Jama. 1992;268: 3452-3455.

4. Levy MM, Fink MP, Marshall JC, et al. 2001 SCCM/ESICM/ACCP/ ATS/SIS International Sepsis Definitions Conference. Crit Care Med. 2003;31:1250-1256.

5. Kirn TJ, Weinstein MP. Update on blood cultures: how to obtain, process, report, and interpret. Clin Microbiol Infect. 2013;19(6):513-520.

6. Kumar A, Haery C, Paladugu B, et al. The duration of hypotension before the initiation of antibiotic treatment is a critical determinant of survival in a murine model of Escherichia coli septic shock: association with serum lactate and inflammatory cytokine levels. J Infect Dis. 2006;193(2):251-258.

7. Dellinger RP, Levy MM, Rhodes A, et al. Surviving sepsis campaign: international guidelines for management of severe sepsis and septic shock, 2012. Intensive Care Med. 2013;39(2):165-228.

8. Paolucci M, Landini MP, Sambri V. Conventional and molecular techniques for the early diagnosis bacteraemia. Int $J$ Antimicrob Agents. 2010;36(Suppl 2):S6-S16.

9. Martin GS, Mannino DM, Eaton S, Moss M. The epidemiology of sepsis in the United States from 1979 through 2000. N Engl J Med. 2003;348(16):1546-1554.

10. Angus DC, Linde-Zwirble WT, Lidicker J, Clermont G, Carcillo J, Pinsky MR. Epidemiology of severe sepsis in the United States: analysis of incidence, outcome, and associate costs of care. Crit Care Med. 2001; 29:1303-1310.

11. Linde-Zwirble WT, Angus DC. Severe sepsis epidemiology: sampling, selection, and society. Crit Care. 2004;8(4):222-226. 
12. Sands KE, Bates DW, Lanken PN, et al. Epidemiology of sepsis syndrome in 8 academic medical centers. JAMA. 1997;278(3):234-240.

13. Mayr FB, Yende S, Linde-Zwirble WT, et al. Infection rate and acute organ dysfunction risk as explanations for racial differences in severe sepsis. JAMA. 2010;303:2495-2503.

14. Angus DC, van der Poll T. Severe sepsis and septic shock. $N$ Engl $J$ Med. 2013;369:840-851.

15. Hall MJ, Williams SN, DeFrances CJ, Golosinskiy A. Inpatient care for septicemia or sepsis: a challenge for patients and hospitals. NCHS Data Brief. 2011;(62):1-8.

16. Adhikari NK, Fowler RA, Bhagwanjee S, Rubenfeld GD. Critical care and the global burden of critical illness in adults. Lancet. 2010; 376(9749):1339-1346.

17. Russel JA. Management of sepsis. $N$ Engl J Med. 2006;355(16): 1699-1713.

18. National Institute of General Medical Sciences. National Institutes of Health. Sepsis fact sheet 2009. Available from: http://www.nigms. nih.gov/Publications/factsheet_sepsis.htm. Accessed September 16, 2015.

19. Moore LJ, Moore FA. Epidemiology of sepsis in surgical patients. Surg Clin North Am. 2012;92:1425-1443.

20. Nordmann P, Gniadkowski M, Giske CG, Poirel L, Woodford N, Miriagou V. Identification and screening of carbapenemase-production Enterobacteriaceae. Clin Microbiol Infect. 2012;18:432-438.

21. Weber DJ, Rutala WA. Central line-associated bloodstream infections: prevention and management. Infect Dis Clin North Am. 2011; 25(1):77-102.

22. Pronovost $\mathrm{P}$, Needham $\mathrm{D}$, Berenholtz $\mathrm{S}$, et al. An intervention to decrease catheter-related bloodstream infections in the ICU. $N$ Engl J Med. 2006;355(26):2725-2732.

23. Lagu T, Rothberg MB, Nathanson BH, Steingrub JS, Lindenauer PK Incorporating initial treatments improves performance of a mortality prediction model for patients with sepsis. Pharmacoepidemiol Drug Saf. 2012;21(Suppl 2):44-52.

24. Mussi C. The sistemic inflammatory reaction syndrome and the multiple organ dysfunction in geriatric medicine. G Gerontol. 2005;53: 151-166.

25. Vincent JL, Sakr Y, Sprung CL, et al. Sepsis in European intensive care units: results of the SOAP study. Crit Care Med. 2006; 34(2):344-353.

26. Opal SM, Garber GE, LaRosa SP, et al. Systemic host responses in severe sepsis analyzed by causative microorganism and treatment effects of drotrecogin alfa (activated). Clin Infect Dis. 2003;37(1):50-58.

27. D'Ancona FP, Caporali MG, Giambi C. Dati di sorveglianza delle malattie batteriche invasive aggiornati al 12 agosto 2015 [Surveillance data on invasive bacterial diseases updated 12 August 2015]. Rapporti della sorveglianza delle malattie batteriche invasive dell'Istituto Superiore di Sanità 2015. Available from: http://www. iss.it/binary/mabi/cont/Report_MBI_20150812_V5.pdf. Accessed September 23, 2015. Italian.

28. Rangel-Frausto MS. The epidemiology of bacterial sepsis. Infect Dis Clin North Am. 1999;13(2):299-312.

29. Deutschman CS, Tracey KJ. Sepsis: current dogma and new perspectives. Immunity. 2014;40(4):463-475.

30. Cohen J. The immunopathogenesis of sepsis. Nature. 2002;420(6917): 885-891.

31. Schulte W, Bernhagen J, Bucala R. Cytokines in sepsis: potent immunoregulators and potential therapeutic targets - an updated view. Mediators Inflamm. 2013;2013:165974.

32. Dinarello CA. Proinflammatory and anti-inflammatory cytokines as mediators in the pathogenesis of septic shock. Chest. 1997;112 (6 Suppl):321S-329S.

33. Hotchkiss RS, Coopersmith CM, McDunn JE, Ferguson TA. The sepsis seesaw: tilting toward immunosuppression. Nat Med. 2009; 15(5):496-497.

34. Hotchkiss RS, Swanson PE, Freeman BD, et al. Apoptotic cell death in patients with sepsis, shock, and multiple organ dysfunction. Crit Care Med. 1999;27(7):1230-1251.
35. Ware LB, Magarik JA, Wickersham N, et al. Low plasma citrulline levels are associated with acute respiratory distress syndrome in patients with severe sepsis. Crit Care. 2013;17(1):R10.

36. Sjövall F, Morota S, Persson J, Hansson MJ, Elmér E. Patients with sepsis exhibit increased mitochondrial respiratory capacity in peripheral blood immune cells. Crit Care. 2013;17(4):R152.

37. Reinhart K, Bauer M, Riedemann NC, Hartog CS. New approaches to sepsis: molecular diagnostics and biomarkers. Clin Microbiol Rev. 2012;25(4):609-634.

38. Pierrakos C, Vincent JL. Sepsis biomarkers: a review. Crit Care. 2010;14(1):R15.

39. László I, Trásy D, Molnár Z, Fazakas J. Sepsis: from pathophysiology to individualized patient care. J Immunol Res. 2015;2015:510436.

40. Doherty M, Wallis RS, Zumla A. Biomarkers for tuberculosis disease status and diagnosis. Curr Opin Pulm Med. 2009;15(3):181-187.

41. Marshall JC, al Naqbi A. Principles of source control in the management of sepsis. Crit Care Clin. 2009;25(4):753-768.

42. Andaluz-Ojeda D, Bobillo F, Iglesias V, et al. A combined score of pro- and anti-inflammatory interleukins improves mortality prediction in severe sepsis. Cytokine. 2012;57(3):332-336.

43. Riedel S, Carroll KC. Laboratory detection of sepsis: biomarkers and molecular approaches. Clin Lab Med. 2013;33(3):4134-4137.

44. Charchaflieh J, Rushbrook J, Worah S, Zhang M. Activated complement factors as disease markers for sepsis. Dis Markers. 2015;2015: 382463.

45. Simon L, Gauvin F, Amre DK, Saint-Louis P, Lacroix J. Serum procalcitonin and C-reactive protein levels as markers of bacterial infection: a systematic review and meta-analysis. Clin Infect Dis. 2004;39(2):206-217.

46. Martini A, Gottin L, Mélot C, Vincent JL. A prospective evaluation of the Infection Probability Score (IPS) in the intensive care unit. J Infect. 2008;56(5):313-318.

47. Claeys R, Vinken S, Spapen H, et al. Plasma procalcitonin and C-reactive protein in acute septic shock: clinical and biological correlates. Crit Care Med. 2002;30(4):757-762.

48. Flood RG, Badik J, Aronoff SC. The utility of serum C-reactive protein in differentiating bacterial from nonbacterial pneumonia in children: a meta-analysis of 1230 children. Pediatr Infect Dis J. 2008;27(2):95-99.

49. Becker KL, Snider R, Nylen ES. Procalcitonin assay in systemic inflammation, infection, and sepsis: clinical utility and limitations. Crit Care Med. 2008;36(3):941-952.

50. Kibe S, Adams K, Barlow G. Diagnostic and prognostic biomarkers of sepsis in critical care. J Antimicrob Chemother. 2011;66 (Suppl 2):ii33-ii40.

51. Müller B, Becker KL, Schächinger $\mathrm{H}$, et al. Calcitonin precursors are reliable markers of sepsis in a medical intensive care unit. Crit Care Med. 2000;28:977-983.

52. Kim KE, Han JY. Evaluation of the clinical performance of an automated procalcitonin assay for the quantitative detection of bloodstream infection. Korean J Lab Med. 2010;30(2):153-159.

53. Marcus R, Paul M, Elphick H, Leibovici L. Clinical implications of $\beta$-lactam-aminoglycoside synergism: systematic review of randomised trials. Int J Antimicrob Agents. 2011;37(6):491-503.

54. Brunkhorst FM, Oppert M, Marx G, et al. Effect of empirical treatment with moxifloxacin and meropenem vs meropenem on sepsis-related organ dysfunction in patients with severe sepsis: a randomized trial. JAMA. 2012;307(22):2390-2399.

55. Vazquez-Grande G, Kumar A. Optimizing antimicrobial therapy of sepsis and septic shock: focus on antibiotic combination therapy. Semin Respir Crit Care Med. 2015;36(1):154-166.

56. Cooper MS, Stewart PM. Corticosteroid insufficiency in acutely ill patients. N Engl J Med. 2003;348:727-734.

57. Bone RC, Fisher CJ Jr, Clemmer TP, Slotman GJ, Metz CA, Balk RA. A controlled clinical trial of high-dose methylprednisolone in the treatment of severe sepsis and septic shock. $N$ Engl J Med. 1987;317:653-658. 
58. Annane D, Sebille V, Charpentier C, et al. Effect of treatment with low doses of hydrocortisone and fludrocortisone on mortality in patients with septic shock. JAMA. 2002;288:862-871.

59. Rivers E, Nguyen B, Havstad S, et al. Early goal-directed therapy in the treatment of severe sepsis and septic shock. N Engl J Med. 2001;345: 1368-1377.

60. Gupta RG, Hartigan SM, Kashiouris MG, Sessler CN, Bearman GML. Early goal-directed resuscitation of patients with septic shock: current evidence and future directions. Crit Care. 2015;19:286.

61. Abraham E, Laterre PF, Garg R, et al. Drotrecogin alfa (activated) for adults with severe sepsis and a low risk of death. N Engl J Med. 2005; 353(13):1332-1341

62. Want L, Brown J, Varki A, et al. Heparin's anti-inflammatory effects require glucosamine 6-O-sulfation and are mediated by blockade of L- and P-selectins. J Clin Invest. 2002;110:127-136.

63. Abraham E, Reinhart K, Opal S, et al. Efficacy and safety of tifacogin (recombinant tissue factor pathway inhibitor) in severe sepsis: a randomized controlled trial. JAMA. 2003;290:238-247.

64. Dellinger RP, Levy MM, Carlet JM, et al. Surviving Sepsis Campaign: international guidelines for management of severe sepsis and septic shock. Crit Care Med. 2008;36(1):296-327.

65. Murray PR, Traynor P, Hopson D. Critical assessment of blood culture techniques: analysis of recovery of obligate and facultative anaerobes, strict aerobic bacteria, and fungi in aerobic and anaerobic blood culture bottles. J Clin Microbiol. 1992;30:1462-1468.

66. Morris AJ, Wilson ML, Mirrett S, Reller LB. Rationale for selective use of anaerobic blood cultures. J Clin Microbiol. 1993;31: 2110-2113.

67. Fenollar F, Raoult D. Molecular diagnosis of bloodstream infections caused by non-cultivable bacteria. Int $J$ Antimicrob Agents. 2007;30(Suppl 1):S7-S15.

68. Archibald LK, Pallangyo K, Kazembe P, et al. Blood culture contamination in Tanzania, Malawi, and the United States: a microbiological tale of three entities. J Clin Microbiol. 2006;44:1425-1429.

69. Leggieri N, Rida A, François P, Schrenzel J. Molecular diagnosis of bloodstream infections: planning to (physically) reach the bedside. Curr Opin Infect Dis. 2010;23(4):311-319.

70. Liesenfeld O, Lehman L, Hunfeld KP, Kost G. Molecular diagnosis of sepsis: new aspects and recent developments. Eur J Microbiol Immunol (Bp). 2014;4(1):1-25.

71. Peters RP, van Agtmael MA, Danner SA, Savelkoul PH, VandenbrouckeGrauls CM. New developments in the diagnosis of bloodstream infections. Lancet Infect Dis. 2004;4(12):751-760.

72. Kim NH, Kim M, Lee S, et al. Effect of routine sterile gloving on contamination rates in blood culture: a cluster randomized trial. Ann Intern Med. 2011;154(3):145-151.

73. Glerant JC, Hellmuth D, Schmit JL, Ducroix JP, Jounieaux V. Utility of blood cultures in community-acquired pneumonia requiring hospitalization: influence of antibiotic treatment before admission. Respir Med. 1999;93(3):208-212.

74. Tissari P, Zumla A, Tarkka E, et al. Accurate and rapid identification of bacterial species from positive blood cultures with a DNA-based microarray platform: an observational study. Lancet. 2010;375(9710):224-230.

75. Gaibani P, Rossini G, Ambretti S, et al. Blood culture systems: rapid detection - how and why? Int J Antimicrob Agents. 2009;34(Suppl 4): S13-S15.

76. Järvinen AK, Laakso S, Piiparinen $P$, et al. Rapid identification of bacterial pathogens using a PCR- and microarray-based assay. BMC Microbiol. 2009;9:161.

77. Lebovitz EE, Burbelo PD. Commercial multiplex technologies for the microbiological diagnosis of sepsis. Mol Diagn Ther. 2013; 17(4):221-231.

78. Aittakorpi A, Kuusela P, Koukila-Kähkölä P, et al. Accurate and rapid identification of Candida spp. frequently associated with fungemia by using PCR and the microarray-based Prove-it Sepsis assay. J Clin Microbiol. 2012;50(11):3635-3640.
79. Mwaigwisya S, Assiri RA, O'Grady J. Emerging commercial molecular tests for the diagnosis of bloodstream infection. Expert Rev Mol Diagn. 2015;15(5):681-692.

80. Ljungström L, Enroth H, Claesson BE, et al. Clinical evaluation of commercial nucleic acid amplification tests in patients with suspected sepsis. BMC Infect Dis. 2015;15:199.

81. Buchan BW, Ginocchio CC, Manii R, et al. Multiplex identification of gram-positive bacteria and resistance determinants directly from positive blood culture broths: evaluation of an automated microarray-based nucleic acid test. PLoS Med. 2013;10(7):e1001478.

82. Scott LJ. Verigene ${ }^{\circledR}$ gram-positive blood culture nucleic acid test. $M o l$ Diagn Ther. 2013;17(2):117-122.

83. Sullivan KV, Turner NN, Roundtree SS, et al. Rapid detection of Gram-positive organisms by use of the Verigene Gram-positive blood culture nucleic acid test and the BacT/Alert Pediatric FAN system in a multicenter pediatric evaluation. J Clin Microbiol. 2013; 51(11):3579-3584

84. Ward C, Stocker K, Begum J, Wade P. Performance evaluation of the Verigene $^{\circledR}$ (Nanosphere) and FilmArray ${ }^{\circledR}$ (BioFire ${ }^{\circledR}$ ) molecular assays for identification of causative organisms in bacterial bloodstream infections. Eur J Clin Microbiol Infect Dis. 2015;34:487-496.

85. Wojewoda CM, Sercia L, Navas M, et al. Evaluation of the Verigene grampositive blood culture nucleic acid test for rapid detection of bacteria and resistance determinants. J Clin Microbiol. 2013; 51(7):2072-2076.

86. Blaschke AJ, Heyrend C, Byington CL, et al. Rapid identification of pathogens from positive blood cultures by multiplex polymerase chain reaction using the FilmArray system. Diagn Microbiol Infect Dis. 2012;74(4):349-355.

87. Altun O, Almuhayawi M, Ullberg M, Ozenci V. Clinical evaluation of the FilmArray blood culture identification panel in identification of bacteria and yeasts from positive blood culture bottles. J Clin Microbiol. 2013;51(12):4130-4136.

88. Poritz MA, Blaschke AJ, Byington CL, et al. FilmArray, an automated nested multiplex PCR system for multi-pathogen detection: development and application to respiratory tract infection. PLoS One. 2011;6(10):e26047.

89. Moussaoui W, Jaulhac B, Hoffmann AM, et al. Matrix-assisted laser desorption ionization time-of-flight mass spectrometry identifies $90 \%$ of bacteria directly from blood culture vials. Clin Microbiol Infect. 2010;16:1631-1638.

90. Stevenson LG, Drake SK, Murray PR. Rapid identification of bacteria in positive blood culture broths by matrix-assisted laser desorption ionization-time of flight mass spectrometry. J Clin Microbiol. 2010; 48(2):444-447.

91. Seng P, Drancourt M, Gouriet F, et al. Ongoing revolution in bacteriology: routine identification of bacteria by matrix-assisted laser desorption ionization time-of-flight mass spectrometry. Clin Infect Dis. 2009;49(4):543-551.

92. Fournier PE, Drancourt M, Colson P, Rolain JM, La Scola B, Raoult D. Modern clinical microbiology: new challenges and solutions. Nat Rev Microbiol. 2013;11(8):574-585.

93. Kok J, Thomas LC, Olma T, Chen SC, Iredell JR. Identification of bacteria in blood culture broths using matrix-assisted laser desorptionionization Sepsityper ${ }^{\mathrm{TM}}$ and time of flight mass spectrometry. PLoS One. 2011;6(8):e23285

94. Werno AM, Christner M, Anderson TP, Murdoch DR. Differentiation of Streptococcus pneumoniae from nonpneumococcal streptococci of the Streptococcus mitis group by matrix-assisted laser desorption ionization-time of flight mass spectrometry. J Clin Microbiol. 2012; 50(9):2863-2867.

95. Ecker DJ, Sampath R, Li H, et al. New technology for rapid molecular diagnosis of bloodstream infections. Expert Rev Mol Diagn. 2010; 10(4):399-415.

96. Kaleta EJ, Clark AE, Johnson DR, et al. Use of PCR coupled with electrospray ionization mass spectrometry for rapid identification of bacterial and yeast bloodstream pathogens from blood culture bottles. J Clin Microbiol. 2011;49(1):345-353. 
97. Jordana-Lluch E, Giménez M, Quesada MD, Ausina V, Martró E. Improving the diagnosis of bloodstream infections: PCR coupled with mass spectrometry. Biomed Res Int. 2014;2014:501214.

98. Kaleta EJ, Clark AE, Cherkaoui A, et al. Comparative analysis of PCRelectrospray ionization/mass spectrometry (MS) and MALDI-TOF/MS for the identification of bacteria and yeast from positive blood culture bottles. Clin Chem. 2011;57(7):1057-1067.

99. Jacob D, Sauer U, Housley R, et al. Rapid and high-throughput detection of highly pathogenic bacteria by Ibis PLEX-ID technology. PLoS One. 2012;7(6):e39928.

100. Kempf VA, Mändle T, Schumacher U, Schäfer A, Autenrieth IB. Rapid detection and identification of pathogens in blood cultures by fluorescence in situ hybridization and flow cytometry. Int $\mathrm{J}$ Med Microbiol. 2005;295(1):47-55.

101. Jansen GJ, Mooibroek M, Idema J, Harmsen HJ, Welling GW, Degener JE. Rapid identification of bacteria in blood cultures by using fluorescently labeled oligonucleotide probes. J Clin Microbiol. 2000; 38(2):814-817.

102. Hall L, Le Febre KM, Deml SM, Wohlfiel SL, Wengenack NL. Evaluation of the Yeast Traffic Light PNA FISH probes for identification of Candida species from positive blood cultures. J Clin Microbiol. 2012;50(4):1446-1448.

103. Moter A, Göbel UB. Fluorescence in situ hybridization (FISH) for direct visualization of microorganisms. J Microbiol Methods. 2000; 41(2):85-112.

104. Forrest GN. PNA FISH: present and future impact on patient management. Expert Rev Mol Diagn. 2007;7(3):231-236.

105. Pletz MW, Wellinghausen N, Welte T. Will polymerase chain reaction (PCR)-based diagnostics improve outcome in septic patients? A clinical view. Intensive Care Med. 2011;37(7):1069-1076.

106. Holtzman C, Whitney D, Barlam T, Miller NS. Assessment of impact of peptide nucleic acid fluorescence in situ hybridization for rapid identification of coagulase-negative staphylococci in the absence of antimicrobial stewardship intervention. J Clin Microbiol. 2011; 49(4):1581-1582.

107. Calderaro A, Martinelli M, Motta F, et al. Comparison of peptide nucleic acid fluorescence in situ hybridization assays with culturebased matrix-assisted laser desorption/ionization-time of flight mass spectrometry for the identification of bacteria and yeasts from blood cultures and cerebrospinal fluid cultures. Clin Microbiol Infect. 2014;20:O468-O475.

108. Forrest GN, Mehta S, Weekes E, Lincalis DP, Johnson JK, Venezia RA. Impact of rapid in situ hybridization testing on coagulase-negative staphylococci positive blood cultures. J Antimicrob Chemother. 2006;58:154-158.

109. Park SD, Lee G, Wang HY, et al. Evaluation of PCR-reverse blot hybridization assay, REBA Sepsis-ID test, for simultaneous identification of bacterial pathogens and mecA and van genes from blood culture bottles. Ann Lab Med. 2014;34(6):446-455.

110. Opota O, Jaton K, Greub G. Microbial diagnosis of bloodstream infection: towards molecular diagnosis directly from blood. Clin Microbiol Infect. 2015;21(4):323-331.

111. Avolio M, Diamante P, Zamparo S, et al. Molecular identification of bloodstream pathogens in patients presenting to the emergency department with suspected sepsis. Shock. 2010;34(1):27-30.

112. Bloos F, Hinder F, Becker K, et al. A multicenter trial to compare blood culture with polymerase chain reaction in severe human sepsis. Intensive Care Med. 2010;36(2):241-247.

113. Sitnik R, Marra AR, Petroni RC, et al. SeptiFast for diagnosis of sepsis in severely ill patients from a Brazilian hospital. Einstein (Sao Paulo). 2014;12(2):191-196.

114. Chang SS, Hsieh WH, Liu TS, et al. Multiplex PCR system for rapid detection of pathogens in patients with presumed sepsis - a systemic review and meta-analysis. PLoS One. 2013;8(5):e62323.

115. Burdino E, Ruggiero T, Allice T, et al. Combination of conventional blood cultures and the SeptiFast molecular test in patients with suspected sepsis for the identification of bloodstream pathogens. Diagn Microbiol Infect Dis. 2014;79(3):287-292.
116. Guido M, Quattrocchi M, Zizza A, et al. Molecular approaches in the diagnosis of sepsis in neutropenic patients with haematological malignances. J Prev Med Hyg. 2012;53:104-108.

117. Mancini N, Carletti S, Ghidoli N, et al. Molecular diagnosis of polymicrobial sepsis. J Clin Microbiol. 2009;47(4):1274-1275.

118. Louie RF, Tang Z, Albertson TE, Cohen S, Tran NK, Kost GJ. Multiplex polymerase chain reaction detection enhancement of bacteremia and fungemia. Crit Care Med. 2008;36(5):1487-1492.

119. Westh H, Lisby G, Breysse F, et al. Multiplex real-time PCR and blood culture for identification of bloodstream pathogens in patients with suspected sepsis. Clin Microbiol Infect. 2009;15(6):544-551.

120. Wallet F, Nseir S, Baumann L, et al. Preliminary clinical study using a multiplex real-time PCR test for the detection of bacterial and fungal DNA directly in blood. Clin Microbiol Infect. 2010;16(6): 774-779.

121. Mühl H, Kochem AJ, Disqué C, Sakka SG. Activity and DNA contamination of commercial polymerase chain reaction reagents for the universal 16S rDNA real-time polymerase chain reaction detection of bacterial pathogens in blood. Diagn Microbiol Infect Dis. 2010;66(1):41-49.

122. Wellinghausen N, Kochem AJ, Disqué C, et al. Diagnosis of bacteremia in whole-blood samples by use of a commercial universal $16 \mathrm{~S}$ rRNA gene-based PCR and sequence analysis. J Clin Microbiol. 2009;47(9):2759-2765.

123. Rogina P, Skvarc M, Stubljar D, Kofol R, Kaasch A. Diagnostic utility of broad range bacterial $16 \mathrm{~S}$ rRNA gene PCR with degradation of human and free bacterial DNA in bloodstream infection is more sensitive than an in-house developed PCR without degradation of human and free bacterial DNA. Mediators Inflamm. 2014;2014:108592.

124. Loonen AJ, Wolffs PF, Bruggeman CA, van den Brule AJ. Developments for improved diagnosis of bacterial bloodstream infections. Eur J Clin Microbiol Infect Dis. 2014;33(10):1687-1702.

125. Orszag P, Disqué C, Keim S, et al. Monitoring of patients supported by extracorporeal membrane oxygenation for systemic infections by broad-range rRNA gene PCR amplification and sequence analysis. J Clin Microbiol. 2014;52(1):307-311.

126. Bloos F, Sachse S, Schmidt KH, et al. Nucleic acid amplification-based pathogen detection in the blood of severe sepsis patients. Crit Care. 2008;12(Suppl 5):P43.

127. Carrara L, Navarro F, Turbau M, et al. Molecular diagnosis of bloodstream infections with a new dual-priming oligonucleotide-based multiplex PCR assay. J Med Microbiol. 2013;62(11):1673-1679.

128. Kommedal Ø, Simmon K, Karaca D, Langeland N, Wiker HG. Dual priming oligonucleotides for broad-range amplification of the bacterial 16S rRNA gene directly from human clinical specimens. J Clin Microbiol. 2012;50(4):1289-1294.

129. Jordana-Lluch E, Giménez M, Quesada MD, et al. Evaluation of the broad-range PCR/ESI-MS technology in blood specimens for the molecular diagnosis of bloodstream infections. PLoS One. 2015; 10(10):e0140865.

130. Jordana-Lluch E, Carolan HE, Giménez M, et al. Rapid diagnosis of bloodstream infections with PCR followed by mass spectrometry. PLoS One. 2013;8(4):e62108.

131. Bacconi A, Richmond GS, Baroldi MA, et al. Improved sensitivity for molecular detection of bacterial and Candida infections in blood. J Clin Microbiol. 2014;52(9):3164-3174.

132. Dodémont M, De Mendonça R, Nonhoff C, Roisin S, Denis O. Performance of the Verigene Gram-negative blood culture assay for rapid detection of bacteria and resistance determinants. J Clin Microbiol. 2014;52(8):3085-3087.

133. La Scola B. Intact cell MALDI-TOF mass spectrometry-based approaches for the diagnosis of bloodstream infections. Expert Rev Mol Diagn. 2011;11(3):287-298.

134. Peleg AY, Tilahun Y, Fiandaca MJ, et al. Utility of peptide nucleic acid fluorescence in situ hybridization for rapid detection of Acinetobacter spp. and Pseudomonas aeruginosa. J Clin Microbiol. 2009;47(3):830-832. 
135. Afshari A, Schrenzel J, Ieven M, Harbarth S. Bench-to-bedside review: rapid molecular diagnostics for bloodstream infection - a new frontier? Crit Care. 2012;16(3):222.

136. Fitting C, Parlato M, Adib-Conquy M, et al. DNAemia detection by multiplex PCR and biomarkers for infection in systemic inflammatory response syndrome patients. PLoS One. 2012;7(6):e38916.

137. Tärnberg M, Jakobsson T, Jonasson J, Forsum U. Identification of randomly selected colonies of lactobacilli from normal vaginal fluid by pyrosequencing of the $16 \mathrm{~S}$ rDNA variable $\mathrm{V} 1$ and $\mathrm{V} 3$ regions. APMIS. 2002;110(11):802-810.

138. Woo PC, Ng KH, Lau SK, et al. Usefulness of the MicroSeq $50016 \mathrm{~S}$ ribosomal DNA-based bacterial identification system for identification of clinically significant bacterial isolates with ambiguous biochemical profiles. J Clin Microbiol. 2003;41(5):1996-2001.

139. Livermore DM, Wain J. Revolutionising bacteriology to improve treatment outcomes and antibiotic stewardship. Infect Chemother. 2013;45(1):1-10.

140. Kropp KA, Lucid A, Carroll J, et al. Draft genome sequence of a Streptococcus agalactiae strain isolated from a preterm neonate blood sepsis patient at the Royal Infirmary, Edinburgh, Scotland. Genome Announc. 2014;2(5):e00875-14.

141. Bas S, Muzzin P, Vischer TL. Chlamydia trachomatis serology: diagnostic value of outer membrane protein 2 compared with that of other antigens. J Clin Microbiol. 2001;39(11):4082-4085.
142. Kaditis AG, O’Marcaigh AS, Rhodes KH, Weaver AL, Henry NK. Yield of positive blood cultures in pediatric oncology patients by a new method of blood culture collection. Pediatr Infect Dis J. 1996;15(7):615-620.

143. Sautter RL, Bills AR, Lang DL, Ruschell G, Heiter BJ, Bourbeau PP. Effects of delayed-entry conditions on the recovery and detection of microorganisms from BacT/ALERT and BACTEC blood culture bottles. J Clin Microbiol. 2006;44(4):1245-1249.

144. Klouche M, Schröder U. Rapid methods for diagnosis of bloodstream infections. Clin Chem Lab Med. 2008;46(7):888-908.

145. Yanagihara K, Kitagawa Y, Tomonaga M, et al. Evaluation of pathogen detection from clinical samples by real-time polymerase chain reaction using a sepsis pathogen DNA detection kit. Crit Care. 2010;14: R159.

146. Obara H, Aikawa N, Hasegawa N, et al. The role of a real-time PCR technology for rapid detection and identification of bacterial and fungal pathogens in whole-blood samples. J Infect Chemother. 2011; 17(3):327-333.

147. Abu-Salah KM, Zourob MM, Mouffouk F, Alrokayan SA, Alaamery MA, Ansari AA. DNA-based nanobiosensors as an emerging platform for detection of disease. Sensors (Basel). 2015; 15(6):14539-14568.
Pathology and Laboratory Medicine International

\section{Publish your work in this journal}

Pathology and Laboratory Medicine International is a peer-reviewed, open access journal focusing on innovative basic research and translational research related to pathology or human disease. The journal includes original research, updates, case reports, reviews and commentaries on current controversies. The Academic Sponsor

\section{Dovepress}

of this journal is the Chinese American Pathology Association (CAPA). The manuscript management system is completely online and includes a very quick and fair peer-review system. Visit http://www.dovepress.com/testimonials.php to read real quotes from published authors.

Submit your manuscript here: http://www.dovepress.com/pathology-and-laboratory-medicine-international-journal 